\title{
Editorial: Listening to the Disciplinary Other
}

It is one of the axioms of a public theology that its practice should be interdisciplinary. That aim is well canvassed and makes a great deal of sense for a discipline which recognizes how its exponents represent one voice among many in a diverse and ever-changing public domain. The standard assumption seems to be that those who are well-versed in the ways of theology and its various sub-disciplines either draw upon the insights of another field of enquiry or collaborate in a dialogical and responsive way to the practitioner of another discipline. This edition of the journal is quite different.

Not one of the contributors in the pages that follow is a trained theologian. For none of them is theology in any of its forms the primary disciplinary driver in their engagement on behalf of the common good and right relations between nations. This cadre of authors all work in the one institution-the highly regarded Australian National University. Their field of expertise lies in global governance, international relations, and programmes of development. They seek to reflect on a raft of global issues from the perspective of their first academic language while seeking to make connections with a Christian profession. It goes without saying that each one of these writers possesses a point of entry and contact into matters of a public and academic debate that often lies beyond that of the theologian, biblical scholar and religious activist and ethicist. It could be argued that this kind of scholarly work carried out by those who also happen to be, in this case Christian, serves as an invitation and model for a deepening dialogue with theology: in terms of participating in the public sphere these authors bring a much-needed specificity of disciplinary expertise.

The first article by Alana Moore examines the way in which a secular academic reading of the contemporary international humanitarian order has tended to side-line 'faith-based reflection'. It has done so even at a time where there is a deepening awareness of the role played by faith-based organizations in the provision of care and assistance. Moore enables theologians to become familiar with a critical turn in International Relations scholarship in recent years. The importance of this critical turn-and hence this corrective-cannot be underplayed. A relentlessly secular approach certainly aspires after a common good in the 'universal' humanitarian order but it does so in a way that marginalizes or ignores altogether the role religion plays in communities-and 
especially those communities receiving aid. It can neglect a whole dimension of meaning-making and community-binding in particular cultures. There is now through this critical turn a 'unique window' for faith-based reflections: Moore argues the case for 'meeting places' where faith-based actors - and, by extension, public theologians — can enrich the humanitarian quest for a more just and flourishing order.

The benefit of particular disciplinary expertise is likewise evident in the work of Terence Halliday on law-making in the global economy. His particular interest lies in the production of laws and regulations that shape global commercial and financial markets. To this end he makes use of current research on who makes global law and how that then happens in a specific United Nations' body—-the United Nations' Commission on International Trade Law. Halliday is writing out of empirical research on the practice of globalization in a specific set of instances: he nevertheless discerns a role for a public theology established in the Christian tradition. He argues that there are distinctive theological principles that can function as middle level axioms and release a foil of 'ethical guidance' to what the research actually uncovers. In terms of who is present, presenting and speaking in an international body the evidence shows that it is likely to be the powerful nations: the most vulnerable peoples may find the manner of proceeding alien, lacks some of their most valued expertise, and their representatives are not as consistently present or asked to voice their interests and concerns: they become 'weak actors'. Halliday suggests that a public theology offers an alternative 'lens' for the sake of human flourishing on a global scale. It presumes the 'inalienable dignity' of every human being and, at its best, insists on justice and fairness. It can be grounded in a Christology from below which respects and privileges the marginalized and critiques unjust exclusion.

For Cecilia Jacob the overriding issues are ones to do with how justice is conceptualized in 'the present-day context of global conflict'. Her interest is in 'scaling up' of theological claims from the personal and communal to the international. In a variation of Halliday's appeal to middle axioms Jacob makes reference to 'mediating biblical principles'. She does so mindful of how these principles can help 'navigate moral choices' but not serve as prescriptive answers to the complex social and political issues that arise in 'territorial bounded nation-state units'. In the service of her argument Jacob models how an academic whose expertise is in an 'other' discipline can draw upon the work of a noted theologian who has informed public theology - in this instance she turns to Reinhold Niebuhr's Christian realism alongside her interest in a political theology of reconciliation. 
Over the last several years there have been multiple articles on the plight and reception of refugees. The focus has invariably fallen upon Europe and, often, the issues of nationalism and cultural diversity. The immediate background to Luke Granville's work is the desire of Donald Trump to build a wall on the border between Mexico and the United States in order to keep out illegal migrants. Granville takes issue with those political theorists and theologians who take issue with the call for a greater generosity toward refugees on three grounds. He argues the case against the appeal to the prerogatives of state sovereignty, the preferential love for fellow-citizens, and the priority of loving nearby neighbours over distant strangers. It is not surprising that Granville makes use of the parable of the good Samaritan and the manner in which it poses the question of who is the neighbour. That is a common enough practice these days. What is especially helpful about Granville's line of approach is the way in which he examines claims to sovereign rights and geographical constraints in identifying who is a neighbour.

For Ben Day the presenting issue has to do with aid-giving behaviour of the traditional donor states now in a time of Covid-19. His fundamental argument insists on the importance of coming to terms with the 'beyond aid' environment by which he means more is required: there is a need to 'go deeper' and consider the impact of the behavioural pattern of donors on those beyond their own borders. Once again Day is drawing upon both disciplinary expertise and experience beyond theology — this time in the field of aid development. In the present context — for the sake of engaging with a public theology — he provides the equivalent of an interlinear reading of aid narratives and the prophetic traditions of Amos.

It is not surprising that writers whose background is in international relations should bring to the table a set of current global issues. In the final article Michael Cohen examines the arguments surrounding how to respond to the posturing of the handful of nations that possess nuclear weapons. The burden of his argument falls upon the policies of the United States over an extended period of time and the recent provocative stances of Kim Jong Un's North Korea. Cohen believes it is incumbent upon a public theology to make the case for eliminating hatred, fear and insecurity. Cohen insists upon the need of 'learning to live with adversaries' rather than to agitate for nuclear threat and conflict.

The kind of empirical research that this group of scholars from the Australian National University perform represents a salutary reminder of the need for public theology to be well-grounded in the issues it seeks to address. Their 
desire to engage with a public theology is a invitation to be interdisciplinary coming from an unexpected quarter - that is, from a discipline other than theology itself.

\section{Clive Pearson}

Editor-in-Chief, Public and Contextual Theology Research Centre, Charles Sturt University, Australia cpearson@csu.edu.au 